\title{
Application of Carrying Capacity Management in Vietnamese National Parks
}

\author{
Tuan Phong Ly and Thi Hong Hai Nguyen
}

\begin{abstract}
Implementing carrying capacity is a prerequisite for national parks striving to meet the three mandates of park management, namely recreational use, conservation and economic value. This study attempts to investigate the application of carrying capacity management in Vietnam's park system and to assess its application for further development of the concept. Findings show that there are three different approaches to the implementation of carrying capacity in Vietnamese parks, including 1) a laissez-faire approach, 2) a relaxed approach, and 3) a strict approach. It is suggested that economic consideration is one of the major constraints to the implementation in developing countries such as Vietnam. This study not only contributes to the literature of the capacity management in national parks, especially in the context of developing countries, but its findings are also valuable for park authorities to achieve the triple mandates of park management.
\end{abstract}

Keywords: Carrying capacity; capacity management; intervention point; national park; park management model; parastatal model; public and for-profit model; visitor management; Vietnam; Asia Pacific 


\section{Introduction}

National parks (NPs) and other protected areas (PAs) are popular tourist destinations (Beunen, Regnerus \& Jaarsma, 2008), and park management often involves a dual mandate of recreational use and conservation (Pigram \& Jenkins, 2006). As a consequence, managers of these sites have found it difficult to balance visitor recreational use and conservation objectives (Ghimire, 2001; Kerkvliet \& Nowell, 2000). Growth in the number of visitors is one of the critical problems in parks and PAs, while increasing demand, falling public appropriations, and receding focus on conservation functions contribute further to the complexity (Brandt \& Holmes, 2011).

Ma, Ryan and Bao (2009, p.2) argue that, in developing countries mandates for parks and PAs management are not only based on recreation and conservation but also on economic value in terms of "the role of national parks as an asset in tourism policies directed by centrally determined economic objectives of income and employment generation”. Sustaining this triple mandate appears to be most challenging in developing countries as economic factors may overshadow ecological considerations (Pigram \& Jenkins, 2006). In order to ensure this mandate and the sustainability of parks and their resources, the concept of carrying capacity and it practices are a vital asset for park management (Eagles \& Hallo, 2013). The extensive literature on carrying capacity, pays anyhow only limited attention to its application to parks and PAs.

In the emerging destination of Vietnam, international and domestic tourist arrivals have increased significantly in recent decades, while nature-based tourism and ecotourism have also experienced tremendous growth (Vietnam National Administration of Tourism, 2017). In response, the Vietnamese government has declared ecotourism to be one of the country's key tourism products and many resources are allocated to the development of NPs (Suntikul, 2010; Suntikul, Butler \& Airey, 2010; The Government of Vietnam, 2003, 2010).

The concept of carrying capacity has also been mentioned in the Vietnamese national policy on NP management. In Article 8 of Regulations No.104/2007/QĐ-BNN on management of ecotourism activities in NPs and nature reserves, the Ministry of Agriculture and Rural Development (2007) requires that authorities and individuals who are operating ecotourism activities for NPs and PAs must "based on physical, ecological, landscape and social impact assessment of ecotourism activities on NPs and PAs, [to] regulate the maximum visitors per day/per site [the environmental carrying capacity]" (p.5). This policy however, includes no follow-up actions or guidelines for further implementation of the concept. Meanwhile, since the Special-Use Forests (SUF) management policy was introduced in 2006, the Vietnamese park system has witnessed a change from a parastatal management model to a co-existing management model (Ly \& 
Xiao, 2016a), also known as the public and for-profit model (Eagles, 2009; More, 2005). These two management models potentially extend their influences on this policy. While the practical implementation of carrying capacity is anyhow largely unknown in Vietnam, even in the rest of Southeast Asia studies on the application of the carrying capacity concept in NP are fragmented and mostly focus on single sites within the parks. Studies deepening the understanding of the concept in this specific context are however scarce.

Considering the absence of related theory and practice, a priority step is to study the implementation evaluation of the concept before putting it into practice (Patton, 2008). This assessment offers detailed, descriptive information about what, how and why the carrying capacity concept is being used (Posavac, 2011). The current study follows this essential line of thought by investigating the current situation of carrying capacity approaches applied to the Vietnamese park system and by assessing its application process for further development. Findings of this study can not only enrich the literature regarding the implementation of carrying capacity in the context of national parks, but also contribute to relevant practical knowledge in the context of developing countries and Vietnam in particular.

\section{Literature Review}

\section{The Concept of Carrying Capacity}

Literature on carrying capacity has blossomed since the 1970s (Kuss, Graefe \& Vaske, 1990; Lime \& Stankey, 1971; Manning, 1985, 1999; Manning, Valliere, Minteer, Wang \& Jacobi, 2000; Shelby \& Heberlein, 1986; Stankey \& Lime, 1973). The World Tourism Organization defines carrying capacity as "the level of visitors' use an area can accommodate” (Buckley, 1999, p. 706). Despite the extent of literature on carrying capacity, its application to parks and PAs is quite limited and has sometimes resulted in failure. The principal difficulty lies in determining how much impact (e.g., soil compaction and visitor crowding) is too much, or how much impact should be allowed in a NP before management intervention is required (i.e., the intervention point) (Manning, 2001). The early stage of carrying capacity development requires no standard of indicators for management reference. Park management records the number of usages to justify visitor capacity. This judgment process is completely subjective for decision making on how much change is acceptable. Moreover, this action means that the intervention point is thoroughly blurred and flexible during the early development stages of carrying capacity.

Manning (2001) offered a visual explanation of the pitfall of the original carrying capacity concept (Figure 1) in terms of the social impact of crowding. Hence, a rising number of visitors (from X1 to X2) increases the percentage of visitors who report 
"feeling crowded" (from Y1 to Y2). However, the point at which effective carrying capacity has been reached (Y1, Y2, or any other point along the Y-axis) remains unclear. Eventually, subjective judgments for how to manage the situation must be made.

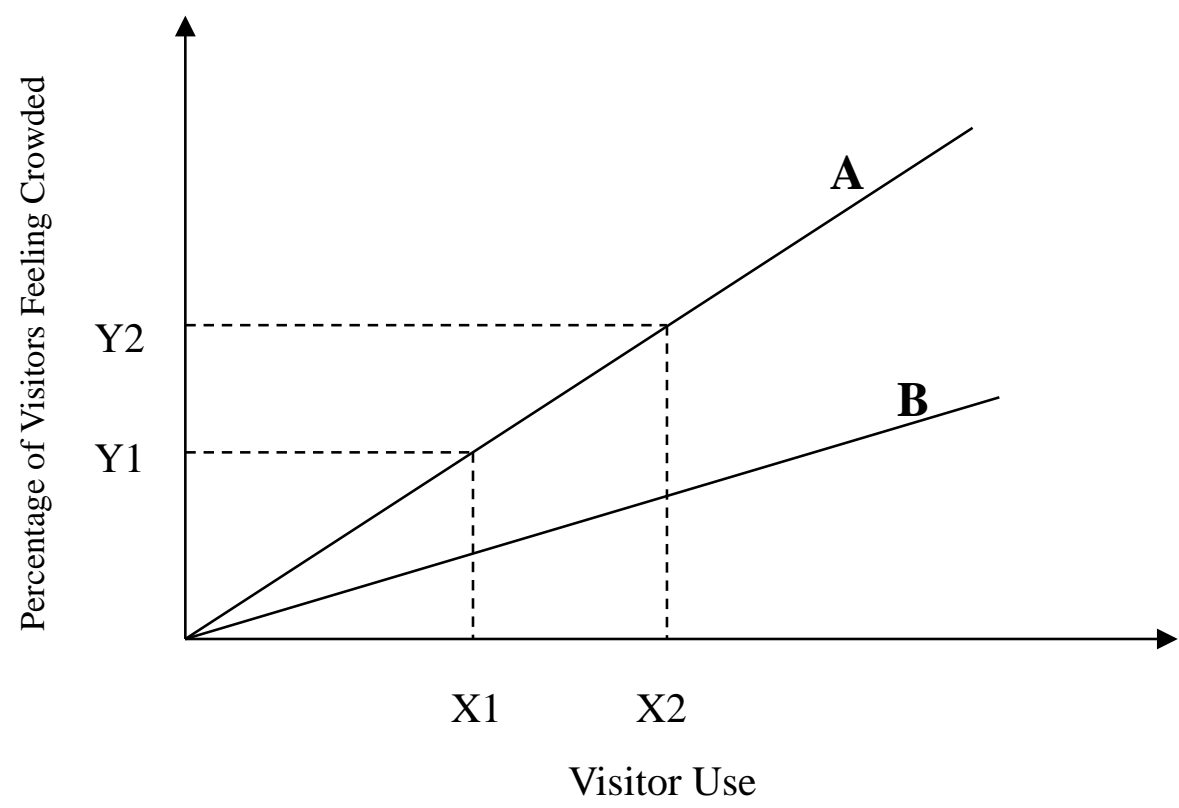

\section{Figure 1. Relationships between Visitor Use and Crowding}

Source: Adapted from Manning (2001).

Despite the conceptual development and potential managerial applications of carrying capacity to outdoor recreation, the concept has been criticized (Plummer, 2009). Lindberg, McCool and Stankey (1997), for example, asserted that definitions of carrying capacity do not provide enough guidance for practical implementation because they rely on subjective values rather than explicit indicators and criteria. They concluded that the traditional notion of carrying capacity should be replaced in favour of alternative visitor management tools and carrying capacity tools for outdoor recreation were established (Lindberg et al., 1997). However, according to Hammitt and Cole (1998, p. 15), "they are not the key to management for which some have been looking. The key to management, in recreation as in range and wildlife management, is specifying management objectives and monitoring conditions”. Alternative visitor management tools have taken the content of management objectives and evaluated conditions in their decision-making process for governing parks and PAs into account.

\section{Alternative Visitor Management Tools}

\section{Management by Objective}

To refine the concept of carrying capacity, some advocates believe that alternative visitor management tools should determine the intervention point of management on a more 
objective platform. One comprehensive solution for these challenges and pitfalls can be found in the literature on the development of management by objective (MBO) alternatives (Manning, 2001).

MBO alternatives include three steps: 1) establish explicit management objectives, 2) choose associated indicators, and 3) use standards of quality (Manning, 2001). Management objectives are clear and detailed statements that define the degree of environmental conservation and the type of visitor experience to be offered in the park. Indicators are measurable and manageable variables reflecting the essence of management objectives. Standards of quality identify the minimum acceptable condition of each indicator variable. By setting management objectives, relevant indicators and standards of quality, managers can ensure that visitor management tools are determined, and then employed through a monitoring process. Related indicator variables can be monitored over time and once standards have been touched, carrying capacity has been reached as well.

MBO approaches that are currently in use as common frameworks for contemporary park and outdoor recreation planning and management include the following: Limits of Acceptable Change (LAC) (Stankey, Cole, Lucas, Peterson, Frissell \& Washburne, 1985), Carrying Capacity Assessment Process (CCAP) (Shelby \& Heberlein, 1986), Visitor Impact Management (VIM) (Graefe, Kuss \& Vaske, 1990) and Visitor Experience and Resource Protection (VERP) (Hof \& Lime, 1997; National Park Service, 1995).

The aforementioned $\mathrm{MBO}$ approaches have been applied in a number of developed countries, such as the United States, Canada and Australia, and are believed to have reached a certain success (Eagles \& McCool, 2002; Pigram \& Jenkins, 2006). However, certain risks due to difficulties in monitoring and evaluating core criteria and standards have been reported (Pigram \& Jenkins, 2006). Consequently, some scholars argue that these MBO approaches have not been applied outside the developed countries for these shortcomings (Payne \& Nilsen, 2008; Plummer, 2009).

The fundamental difference between the original concept of carrying capacity and the MBO alternatives is the judgment of intervention point. The MBO concept focuses on design conditions (e.g., environmental and experiential ones) rather than number of visitors, as in the original carrying capacity concept. Undeniably, the MBO concept is more objective than the original one. However, when standards are violated, the MBO concept requires that management actions are taken. These judgments are inherently subjective in nature and are normally based on the social and political preferences of one or more that people consider acceptable or unacceptable. Therefore, we can consider that MBO concept just 'delay' the human interaction after breaking the rules set up by park 
managers before. When overcrowded situation happened, park managers no longer ensure that environmental degradation is minimized. Rather, park managers must ensure that degradation is within limits that humans have judged as acceptable or unacceptable.

\section{Decision Rules}

Prato (2009) stated that contemporary social and environmental carrying capacities (especially the MBO alternatives) can be assessed using a crisp, stochastic, or fuzzy decision rule. The presence of internal and external forces in natural areas make it difficult for park managers to achieve the triple mandates of park management, which are recreation use, conservation and economic value (Leopold, Cain, Cottam, Garibelson \& Campbell, 1963). On the one hand, park managers have little or no control over external forces, such as changes in vegetation, water supply, climate change on fire regime, air pollution and loss and degradation of wildlife habitat. Hence, managers have little ability to reduce those adverse impacts on parks and PAs. On the other hand, park managers have considerable control over internal forces, such as human use of park resources and facilities (Prato, 2009). Prato (2009) pointed out two factors that limit the ability of park managers to ease the adverse ecosystem impacts of internal forces, including: 1) uncertainty about the current status of the park ecosystem with respect to those forces, and 2) uncertainty about how the park ecosystem reacts to alternative management actions for alleviating adverse impacts of those forces.

Most of the methods of the original concept of carrying capacity and the MBO alternatives (e.g., LAC, VIM and VERP) were based on the crisp decision rule, and failed to consider the two uncertainty factors of internal forces. Prato (2009) stated that "a crisp decision rule is valid when observed indicators are non-stochastic and the relationship between observed indicators and the degree of ecosystem consistency with carrying capacities is precise or known with certainty” (p.2552). A crisp decision rule does not consider sampling and measurement errors in the monitoring of indicators, nor does it consider stochastic variability in the indicators. These omissions can result in management decision errors (Prato, 2009). For example, when mean user satisfaction of twelve months is below the minimum acceptable level of the park, the manager would assume that carrying capacity has been being exceeded in this year. As too many visitors have caused user satisfaction to fall below the minimum acceptable level. This is misleading decision errors because the mean levels only cannot represent all month periods and a further check of each month's figure is needed to avoid this management decision error.

Unlike the crisp decision rule, a stochastic decision rule considers the stochastic variability in observed indicators; therefore the rule could reduce the likelihood of making management decision errors when drawing inferences about user capacity from 
observations on an ecosystem indicator (Prato, 2007). Use of stochastic decision rule requires park managers to detail probability distributions for observed indicators under present and future management actions. This kind of probability distribution can be obtained by using consensus methods such as the Delphi method (Linestone \& Turoff, 1975), or simulation models such as the Multiple Attribute Scoring Test of Capacity (Prato, 2001). However, park managers may not have access to the experts needed to apply these complicated methods and/or they may be unwilling to specify (or incapable of specifying) such probability distributions (Prato, 2009).

The fuzzy adaptive management approach aims "to determine whether a protected area ecosystem is consistent with ecological and social carrying capacities, if not, to identify management actions that are most likely to achieve consistency when there is uncertainty about the current degree of consistency and how alternative management actions are likely to influence that consistency" (Prato, 2009, p.2551). A fuzzy decision rule is based on fuzzy logic, which is a mathematical way of representing the vague or approximate nature of decision-making under uncertainty (Andriantiatsaholiniaina, Kouikoglou \& Phillis, 2004; Klir \& Yuan, 1995). This rule accounts for stochastic variation in the indicator as well as vagueness and uncertainty in the relationship between the observed indicator and the degree of ecosystem consistency with carrying capacity. Prato (2009) found that fuzzy logic is well fitted to infer ecosystem consistency with the concept of carrying capacity when observations are subject to errors and uncertainty about the relationship exists between the indicator and the ecosystem consistency. More importantly, a fuzzy decision rule does not have the above mentioned limitations associated with crisp and stochastic decision rules, which may add extra cost in implementing the carrying capacity concept (Prato, 2009). Parks and PAs could use a web-based, interactive and spatial decision support tool (Loucks, 1995; Sugumaran, Meyer \& Davis, 2010) to improve the ability of managers in implementing the proposed fuzzy decision rule and fuzzy adaptive management approach. Although decision rules, especially the fuzzy decision rule, are very promising in park management to overcome the limits of MBO approaches (Prato, 2009), it is rarely found any parks applying the rules in capacity management (Prato, 2012).

\section{Evolution of Carrying Capacity in Park Management}

Carrying capacity was first suggested in the mid-1930s as a park management concept in the context of NPs (Sumner, 1936). The first accurate application of the concept to park management did not occur until the 1960s (Dasmann, 1964). The literature on carrying capacity and its alternatives has been developed extensively in recent decades (Prato, 2009). Lindberg et al. (1997) suggested that carrying capacity remains a good idea to propose, but a political nightmare to implement. 
After 40 years of development, efforts to determine and to apply carrying capacity approach to NPs have sometimes failed, and even in developed countries, they are limited (Manning, 2001). The concept remains vague, and the lack of a fixed deterministic approach is unpragmatic for planning and management (Simón, Narangajavana \& Marqués, 2004). For developing or under-developed countries, this vagueness may lead to reluctance to apply the carrying capacity concept in the planning and management of parks and PAs. However, there is one rule-of-the-thumb that park managers could decide on, which is the subjective/objective extent of intervention point in park capacity management (Figure 2). It is ranged from extreme subjective to extreme objective. Literature has proved that both extremes are either out-of-dated (i.e., the original concept of carrying capacity) or difficult to practice in reality (i.e., the decision rules). What park managers can do is keeping the visitor capacity management between these two extremes and revising the $\mathrm{MBO}$ approach according to its up-to-date management objectives, indicators and standards for sustainability (Manning, 2001).

\section{Subjective Intervention Point of Carrying Capacity Objective \\ Original Management by Objectives concept of $\mathrm{CC} \quad$ (using objectives, indicators \& quality standards) \\ Decision Rules \\ (consider external and internal forces, management decision errors...)}

\section{Figure 2. Review of Intervention Point of Carrying Capacity Concept}

\section{Studies of National Park Management in Vietnam and Southeast Asia}

Literature on park management in Vietnam focuses on the implications of political change on NP operations (Suntikul et al., 2010) since the update of the new SUF's management policy in 2006 (Suntikul, 2010; The Government of Vietnam, 2010). Several studies were conducted to investigate the application of the new park management model in different parks of Vietnam, including Cuc Phuong, Cat Tien and Phong Nha- Ke Bang NPs (Ly \& Xiao, 2016a, 2016b; Nguyen, Bush \& Mol, 2016).

Regarding to carrying capacity, Vietnamese scholars have studied the concept and referred it to various aspects, including infrastructure, ecology, psychology, economy, society and management (Le, Thai, Nguyen, Le, Thai \& Vo, 2009). The indicators of the concept were yet borrowed them from the Western literature. Tran, Nguyen, Nguyen, Dang and Dinh (2007) adopted the ecological, economic and social carrying capacity formulas developed by Cifuentes (1992) and Ceballos-Lascurain (1996) to calculate the carrying capacities for Phong Nha- Ke Bang and Dong Hoi areas. Vo (2008) also applied two formulas developed by Cifuentes (1992) and Ceballos-Lascurain (1996) to the case 
of Vietnam in order to provide practical guidelines regarding the use of carrying capacity assessments as a manage tool. As mentioned in literature, the calculating method of these formulas is out-of-dated. On the one hand, the capacity was calculated based on number of visitor rather than any conditions using in the MBO approach (Figure 1). On the other hand, although these studies have proposed the exact maximum number of visitors for certain tourist sites of the parks as a reference for future planning, it did not consider the current condition of Vietnamese park system. These formulas are therefore doubtfully applicable and currently in use in Vietnamese national parks.

In the wider area of Southeast Asia, studies related to the application of carrying capacity have been conducted in other countries. These research, however, mostly are based on case-study of a single NP such as Kaula Tahan NP in Malaysia (Ismail, Jaafar \& Mohamad, 2015), and Khao Leam Ya Mu Ko Samed NP in Thailand (Emphandhu, Yemin, Pattanakiat, Tantasirin, Ruschano, Chettamart \& Nasa, 2006). The capacity numbers were calculated in terms of social, physical, ecological and facility aspects (i.e., the original concept of carrying capacity). Similar to carrying capacity studies in Vietnam, these cases also focused on the determination and suggestion of a proper capacity number in each tourist site for future planning (Emphandhu et al., 2006; Ismail et al., 2015). A few studies have investigated the development of NP system of the whole country-such as ICEM (2003) about Lao NPs, and Mekong Protected Areas (2003) about Cambodian park system. However, none of them have investigated into what and why park management has applied the capacity management in real practices. Once again, there is lack of cause-and-effect study regarding application of carrying capacity management in those national park systems (Patton, 2008). Hence it is not easy to stimulate park management to implement this controversial concept (Posavac, 2011). This research considers the understanding of the current application of capacity management in park system is the very first step for further development of visitor management tool. The literature showed that carrying capacity approach is not widely applied in the Southeast Asia region (Emphandhu et al., 2006; Ismail et al., 2015). Thus, with this study we hope to contribute to the growing knowledge of the carrying capacity implementation in Vietnam as well as in Southeast Asia in general. It also aims at discovering the reasons for the insufficient application in the region.

\section{Methodology}

After reviewing the development of the concept of carrying capacity and its alternative visitor management tools, we developed interview questions for in-depth interviews. Manning (2001) and Prato (2009) claim that by studying which carrying capacity method is used and how it works, its application in a national park system can be elaborated. Qualitative research uses selective methods of participant recruitment or purposeful 
sampling (Hennink, Hutter \& Bailey, 2011). At first, the interview questions we designed were sent by email to various park management boards in Vietnam. We obtained contact emails from Vietnamese national parks' websites. Despite this attempt at contacting the relevant board members for interviews, however, we received no response from this method.

Next, we tried other methods to approach potential interviewees. We used our connections with park managers and scholars in Vietnam to recruit potential interviewees. We reached three parks (i.e., PNKB, Ba Vi and Cuc Phuong NPs). At the same time, we also visited NPs in person and directly requested interviews. In this way, we reached contacts from two NPs (i.e., Phu Quoc and Con Dao NPs). In the end, we looked at a total of five parks for this study and we discovered the various aspects of carrying capacity application in Vietnam.

Data for this research were collected from March 2014 to August 2016 in five NPs across Vietnam. The researchers travelled to the parks for day visit and interviewed park management staff. The number of participants for interview is determined by the principle of saturation (Glaser \& Strauss, 1967). We stopped visiting new parks and recruiting interviewees at the point when no new information was being obtained (Hennink et al., 2011). In total, interviews of twelve people were conducted at the five parks. Nine were park management staff from the public sector, which has a major influence in the governing of carrying capacity in Vietnam's parks (Ministry of Agriculture and Rural Development, 2011). The other three interviewees were managers of private tourism companies in the PNKB NP, with insight into how the national park management board was applying the visitor management tools. To "enhance contextual richness and minimize fragmentation” (Foster, 2004, p.230), all participants were interviewed in their work environment or at tourism sites in the parks (Table 1).

Table 1. The Five Vietnamese National Parks in This Study

\begin{tabular}{|c|c|c|c|c|c|c|}
\hline No. & $\begin{array}{l}\text { Name of } \\
\text { Parks }\end{array}$ & Region & $\begin{array}{l}\text { Time of } \\
\text { Visit }\end{array}$ & $\begin{array}{l}\text { Approached } \\
\text { by }\end{array}$ & $\begin{array}{l}\text { No. of } \\
\text { Interviewees }\end{array}$ & Titles of Interviewees \\
\hline 1 & $\begin{array}{l}\text { Phong Nha- } \\
\text { Ke Bang }\end{array}$ & $\begin{array}{l}\text { North } \\
\text { Central } \\
\text { Coast }\end{array}$ & $\begin{array}{l}\text { March } \\
2014 \text { and } \\
\text { November } \\
2015\end{array}$ & $\begin{array}{l}\text { Researcher's } \\
\text { connection }\end{array}$ & 5 & $\begin{array}{l}\text { Deputy manager; manager of } \\
\text { stated management sites; } \\
\text { manager of Truong Thinh } \\
\text { Group; manager of Oxalis } \\
\text { Company; manager of Phong } \\
\text { Nha Discovery Company }\end{array}$ \\
\hline 2 & Phu Quoc & $\begin{array}{l}\text { Mekong } \\
\text { Delta }\end{array}$ & $\begin{array}{l}\text { December } \\
2015\end{array}$ & $\begin{array}{l}\text { Walk-in field } \\
\text { trip }\end{array}$ & 2 & $\begin{array}{l}\text { Head forest ranger; officer of } \\
\text { park management board }\end{array}$ \\
\hline
\end{tabular}


This is a post-referred version of the paper published in Asia Pacific Journal of Tourism Research, 22:10, 1005-1020, DOI: 10.1080/10941665.2017.1359194

\begin{tabular}{llllll}
\hline \multirow{3}{*}{ Ba Vi } & $\begin{array}{l}\text { Red River } \\
\text { Delta }\end{array}$ & July 2016 & $\begin{array}{l}\text { Researcher's } \\
\text { connection }\end{array}$ & $\begin{array}{l}\text { Deputy park director; } \\
\text { manager of park tourism } \\
\text { center }\end{array}$ \\
\hline \multirow{2}{*}{ Cuc Phuong } & $\begin{array}{l}\text { Red River } \\
\text { Delta }\end{array}$ & July 2016 & $\begin{array}{l}\text { Researcher's } \\
\text { connection }\end{array}$ & $\begin{array}{l}\text { Manager of park tourism } \\
\text { center }\end{array}$ \\
\hline \multirow{2}{*}{ Con Dao } & Southeast & $\begin{array}{l}\text { August } \\
2016\end{array}$ & $\begin{array}{l}\text { Walk-in field } \\
\text { trip }\end{array}$ & 2 & $\begin{array}{l}\text { Manager of park tourism } \\
\text { center; head forest ranger }\end{array}$ \\
\hline
\end{tabular}

Interviews were audio-taped after obtaining participant consent. Researchers also took notes and wrote diaries during the field trips. Digital voice recordings were transcribed and translated from Vietnamese to English verbatim by the researchers whose first language is Vietnamese. Due to the exploratory nature of the study, the qualitative content analysis approach guided the data analysis (Hsieh \& Shannon, 2005; Mayring, 2000). NVivo 10 was used in the analyses of interview transcripts (Bazeley, 2007; QSR International, 2016) in terms of storage, organization, coding and management of the collected data.

This study followed the four criteria (i.e., credibility, transferability, dependability and confirmability) of Lincoln and Guba (1985) to evaluate quality of research. Credibility was established mainly through member checking and peer debriefing. Member checking was used in three ways at various stages of data collection and data analysis: 1) at the early stage, the researchers discussed the interview questions with participants of PNKB NP through email and telephone, as the interviewees have worked with the researchers for prolonged studies in many years; 2) during formal interviews, the researchers fed ideas back to participants to refine, rephrase and interpret; 3) in an informal post-interview session, each participant was given the chance to discuss the findings and provide feedback on the transcripts of their own interview as well as evaluate the research findings in their own wills. Peer debriefing was used in the research to “confirm interpretations and coding decisions including the development of categories" (Foster, 2004, p.231). The transferability of the study was ensured by rich description and reporting of the data collection and analysis process. The issues of dependability and confirmability were addressed through the authors' research notes, which recorded decisions, queries, working out and the development results (Hennink et al., 2011).

\section{Findings}

Site visits and interviews firstly offer an overview of the five studied parks. The overview regarding core value, management model and tourism activities is presented in Table 2. 
This is a post-referred version of the paper published in Asia Pacific Journal of Tourism Research, 22:10, 1005-1020, DOI: 10.1080/10941665.2017.1359194

Among the five studied sites, Phu Quoc NP was not open to the public and did not have a plan for future tourism development, so carrying capacity was not a concern and no further discussion was generated on the subject.

Table 2. Management Model and Tourism Development of Five Studied Parks

\begin{tabular}{|c|c|c|c|c|c|}
\hline No & $\begin{array}{c}\text { Name of } \\
\text { national } \\
\text { parks }\end{array}$ & $\begin{array}{l}\text { Management } \\
\text { model }\end{array}$ & $\begin{array}{l}\text { Tourism } \\
\text { management } \\
\text { board }\end{array}$ & Core value & Major tourism activities \\
\hline 1 & $\begin{array}{l}\text { Phu } \\
\text { Quoc }\end{array}$ & Parastatal & $\begin{array}{l}\text { NPMB, Park } \\
\text { Tourism } \\
\text { Center }\end{array}$ & $\begin{array}{l}\text { Marine island } \\
\text { park; established } \\
\text { in } 2001\end{array}$ & $\begin{array}{l}\text { Core zone of the park has not open-to- } \\
\text { public for any tourism activity. }\end{array}$ \\
\hline 2 & $\begin{array}{l}\text { Phong } \\
\text { Nha - } \\
\text { Ke Bang }\end{array}$ & $\begin{array}{l}\text { Co-existing } \\
\text { management } \\
\text { model } \\
\text { (Public and } \\
\text { for-profit) }\end{array}$ & $\begin{array}{l}\text { NPMB, Park } \\
\text { Tourism } \\
\text { Center, three } \\
\text { private } \\
\text { companies }\end{array}$ & $\begin{array}{l}\text { Mountainous } \\
\text { terrain; } \\
\text { established in } \\
\text { 2001; nominated } \\
\text { as World Heritage } \\
\text { Site since } 2003\end{array}$ & $\begin{array}{l}\text { Well-known as most-visited cave } \\
\text { system in Vietnam. Park Tourism } \\
\text { Center operating five mass sites while } \\
\text { Truong Thinh Group manages one mass } \\
\text { site in the core zone. There are some } \\
\text { adventure tours to the strictly protected } \\
\text { area monitoring by NPMB. }\end{array}$ \\
\hline 3 & $\mathrm{Ba} \mathrm{Vi}$ & Parastatal & $\begin{array}{l}\text { NPMB, Park } \\
\text { Tourism } \\
\text { Center }\end{array}$ & $\begin{array}{l}\text { Mountainous } \\
\text { terrain; } \\
\text { established in } \\
1991\end{array}$ & $\begin{array}{l}\text { Featured by rich and diverse tropical } \\
\text { and subtropical species of flora and } \\
\text { fauna, and a place of spiritual tourism of } \\
\text { Vietnamese. All seven mass sites are } \\
\text { managed by Park Tourism Center. }\end{array}$ \\
\hline 4 & $\begin{array}{l}\text { Cuc } \\
\text { Phuong }\end{array}$ & Parastatal & $\begin{array}{l}\text { NPMB, Park } \\
\text { Tourism } \\
\text { Center }\end{array}$ & $\begin{array}{l}\text { Mountainous } \\
\text { terrain; First NP } \\
\text { in } 1962 .\end{array}$ & $\begin{array}{l}\text { Featured as the country's largest nature } \\
\text { reserve, with three conservation } \\
\text { programs for primate, carnivore and } \\
\text { pangolin and turtle. } \\
\text { Park Tourism Center operating a } \\
\text { number of paths for mass tourists to visit } \\
12 \text { sites in park. }\end{array}$ \\
\hline 5 & $\begin{array}{l}\text { Con } \\
\text { Dao }\end{array}$ & Parastatal & $\begin{array}{l}\text { NPMB, Park } \\
\text { Tourism } \\
\text { Center }\end{array}$ & $\begin{array}{l}\text { Marine island } \\
\text { park since 1993; }\end{array}$ & $\begin{array}{l}\text { Characterized by a diverse ecosystem } \\
\text { with rare species such as sea turtles, } \\
\text { dolphins and endangered dugongs are } \\
\text { found. Park Tourism Center operated } \\
\text { nine sightseeing sites and eight } \\
\text { snorkeling sites }\end{array}$ \\
\hline
\end{tabular}

All interviewees from the visited parks affirmed that they were aware of the concept of carrying capacity. However, their knowledge on park management regarding carrying 
capacity was rather basic and limited. Only a few of them knew of the well-known alternative tools such as LAC, CCAP, VIM and VERP. Most interviewees reported that there was neither scientific research nor official guidelines for the implementation of carrying capacity policy in Vietnam’s park system. One interviewee from Ba Vi NP even affirmed that "there is no NP in Vietnam that has thoroughly studied or applied carrying capacity into park operation”. However, in Con Dao NP, the informant indicated that the park had begun applying carrying capacity management in its tourism operation in early 2016. This was the only NP that was fully applying carrying capacity in its management. It is perhaps worth nothing that these findings reveal a lack of communication and dialogue between the various park management boards.

Three approaches to the implementation of carrying capacity in Vietnamese NP were found, including laissez-faire approach, relaxed approach and strict approach. Meaning and operation of each approach are presenting in the next sections. The intervention point is also analysed for each approach, as this is the most essential part of capacity management (Manning, 2001). The following aspects are considered: 1) method or means of managing tourist arrivals, 2) the largest tourist arrival numbers, 3) the decision regarding intervention point, 4) the degree of subjective intervention, and 5) method of managing an over-crowded situation and its solution.

\section{The Laisser-faire Approach: The Cases of Ba Vi and Cuc Phuong NPs}

The first situation is called the laissez-faire approach. This approach, adopted by $\mathrm{Ba} \mathrm{Vi}$ and Cuc Phuong NPs, involves zero regulation from local authorities. The park management boards of these two parks reported that they currently do not have any regulations regarding carrying capacity management. Ba Vi and Cuc Phuong NPs let their visitors decide what to do within their grounds. They provide no guidelines, updates, or communication about where to go after entering the park, even during peak visiting days. When over-crowding happens, the park management boards make decisions on a caseby-case basis to address the issues.

To calculate the numbers of daily tourist arrivals, both Ba Vi and Cuc Phuong NPs use ticket sales. For each of these parks, the largest average number was around 1,000 tourists per day. However, Ba Vi NP reported that there are some special days when overcrowding occurs, with 5,000 to 7,000 visitors. None of the interviewees at both parks considered that the number of 1,000 tourists per day causes any carrying capacity issues. They argued that the design of tour routes in their parks can accommodate more tourists. These parks are normally located within mountainous terrains, which are easy to set up as route-travel with various tourism sites. Thus, tourists can easily change their routes if they feel over-crowded. The parks' tourism managers believed that tourists have a selfadjust ability for deciding where to go after entering the parks. One interviewee of $\mathrm{Ba} \mathrm{Vi}$ 
NP stated that “we don't have this idea of intervention point, because we don't apply any carrying capacity management here". However, there was a "one incident on one day when we [Ba Vi NP] had to intervene in the arrival of tourists and we had to stop selling tickets”. In February 2015, there were 3,000 to 5,000 people coming to the park at sunset due to rare snowy weather in the region. The park management decided to stop selling tickets and close the entrance gate in order to remove any potential danger to the visitors. This intervention was highly subjective, passive and came on a case-by-case basis.

Interviewees at Cuc Phuong NP also reported no intervention from the park and provided further explanation. Although a government decree states that Vietnamese NPs should only offer ecotourism (Ministry of Agriculture and Rural Development, 2007; The Government of Vietnam, 2010), the main source of tourists visiting parks is mass-market tourism. In Vietnam, the park system is put under pressure from the Central Financial Department to meet certain annual targets (i.e., quotas on tourism tax revenues and number of tourists). Therefore, most parks in Vietnam are focused on meeting these targets and rather than limit tourist arrivals, they actually encourage mass tourists. Pigram and Jenkins (2006) argue that economic considerations may be overshadowing ecological factors. This is certain in the case of developing countries such as Vietnam. This phenomenon was mentioned by the Ba Vi NP and PNKB NP interviewees.

\section{The Relaxed Approach: The Case of Phong Nha- Ke Bang NP}

The second situation is referred as the relaxed approach. This approach is used at PNKB NP. This NP has adopted the most up-to-date model of park management, which involves a collaboration of the public and private sectors. Our interviewees represented both sectors. Both the public and private sector interviewees claimed that the park did not regularly apply any carrying capacity tools for managing tourist arrivals. Our findings indeed show that all mass sites in the administrative and service area managed by the park tourism center and by Truong Thinh Group do not have any regulations regarding carrying capacity in their daily operations. The management team only interferes in rare cases when they 'felt' overcrowding. However, for the adventure tours, which involve trekking into the strictly protected area of the park-such as Hang En and Son Doong caves - there is an established limit to the number of tourists. For example, a maximum of 16 people can enter the Hang En cave at one time (Ly, 2015). Thus, with this approach, the park management team can apply different policies for various cases and for different sites.

Similar to the Ba Vi and Cuc Phuong parks, PNKB NP uses tickets to count and control tourist arrivals. The largest average number of visitors for each cave is from 5,000 to 6,000 per day. An officer at the park tourism center reported that beyond this number, the caves would become over-crowded or blocked. The park management indeed 
intervened with tourist arrivals in these cases. The park stopped selling tickets and also controlled the number of boats entering the caves. PNKB NP is a famous tourism spots due to its World Heritage Site status. Thus, the park has to control tourism arrivals more often than other parks, especially during national holidays and peak seasons.

The intervention point decision was made by the park management based on their own judgment and feelings. The deputy manager said, “we don’t use any international [carrying capacity] method to measure the number of tourists in one square meter or anything like that. It is just based on how we feel about the situation. It is solely a qualitative approach, not a quantitative one”. He even claimed that this was how it is done in the whole Vietnamese park system. This degree of intervention seems to be too subjective. Another informant disclosed, "the trend now in Vietnam focuses strongly on economic or commercial benefits. So, the management of park tourism centers focus on making sure that tourists can visit and they don't really consider conservation issues”. This echoes the earlier discussion regarding the case in which carrying capacity is not implemented. Economic benefits seem to be the main emphasis in Vietnam's parks.

Undoubtedly, park management objectives are consistent with the concept of sustainability (World Commission on Environment and Development, 1987), which is summarized as follows: "sustainable development is development that meets the needs of the present without compromising the ability of future generations to meet their own needs” (p.43). This explains why it is only ecotourism that is officially accepted as a form of tourism management in the Vietnamese park system (The Government of Vietnam, 2006). More influential than the national policy, the non-sustainable development culture in Vietnam could become a barrier for parks to the achievement of sustainable development (Ly \& Xiao, 2016a). One interviewee explained the non-sustainable development culture by comparing the tourism management philosophy of the Vietnamese with a fruit-harvesting activity: "people like to harvest the ripe fruit, and destroy the unripe fruit at the same time, not saving it for the next generation”. Managers in both the public and private sectors of PNKB NP and in other parks agreed with this management philosophy. This is a negative sign that inhibits the application of carrying capacity in parks. When choosing between conservation and economic benefits, it seems most managers go for the latter. One management team, however, in the park tourism center, claimed that they would be willing to use international carrying capacity methods to manage tourism arrivals. The challenges are that they have no personnel with the adhoc knowledge to execute, and they lack support from the central government.

Meanwhile, with the control and support from a professional organization, the management of carrying capacity does exist. There are some "signature tours" to the strictly protected area of the park using maximum numbers to control tourist accessibility 
(as previously mentioned, 16 people is the limit for Hang En Cave; for Son Doong Cave, the limit is 10 people). After several years of operation, the park management reported that all tours followed carrying-capacity guidelines, and that no tours exceeded the allowed numbers of tourists. However, when asked how the intervention point was determined, the park tourism center could not answer. All these adventure tours were in fact under the direction and guidance of the British Caving Association (BCA). The BCA had offered professional guidelines in how to operate ecotourism tours to the core zone of the park. The park management board could just take the advice of the BCA in implementing carrying capacity management, yet the park managers have no idea how to calculate those numbers by themselves. This finding indicates that although carrying capacity management exists in PNKB, it was only passively executed at the park.

\section{The Strict Approach: The Case of Con Dao NP}

The third situation is termed as the strict approach. This approach is taken by Con Dao NP. The informants at Con Dao NP reported a newly approved decision regarding regulations on environmental carrying capacity management for all tours and ecotourism sites within the park (Con Dao National Park Management Board, 2016). The legal basis of this decision was Decision No.104/2007 of the Ministry of Agriculture and Rural Development (Ministry of Agriculture and Rural Development, 2007), and the practical basis was the book Protecting Tourism Environment (Le, 2015). Con Dao NP establishes the maximum numbers of tourists for all its tourism sites, including nine land sites and eight underwater snorkelling sites. The management of Con Dao NP is unique in the Vietnamese park system. The public-sector management arm in this park has actively extended and applied the government's policy on carrying capacity in the park's tourism activities, while the other parks claimed they are not applying the policy due to the lack of guidelines and support from the central government. The initiative of Con Dao NP suggests that the other parks in Vietnam could change their approaches regarding implementation of carrying capacity policy. The problem appears to lie in the will to change of the park management teams.

According to the manager of the park tourism center, Con Dao NP is proudly the only park in Vietnam applying carrying capacity completely - that is, in all the tourism sites within the park’s territory (Con Dao National Park Management Board, 2016). The park uses tickets to count and control tourist arrivals. The number of tickets allowed for sale is based on a calculation made in advance-the maximum number before reaching the intervention point. For this reason, Con Dao NP is unlike any other park in Vietnam's park system, wherein we have seen that a park management board may make a decision to intervene after simply "feeling” over-crowded. Con Dao NP calculated in advance the maximum accepted number for each tourism site, both for daytime and night visits, using 
the total site area divided by the average number of total tourist arrivals in the past. The calculation of the average number of tourist arrivals is decided based on the following factors: the largest and smallest numbers in the past year; the change in arrival numbers during the high and low seasons of the last year; and the reaction of the natural environment to the tourist arrival numbers (i.e., matching the concept of fuzzy decision rule (Prato, 2009)). For example, the maximum numbers for the sandy beach of Bay Canh island in 2016 are 48 people for daytime visits and 24 people for night visits, based on 2015 data (Con Dao National Park Management Board, 2016).

When tourist arrivals exceed the maximum number at a site, the park management makes further arrangements based on two scenarios. First, if the number of tourist arrivals is only slightly above the maximum, then the park management makes an exception and allows additional tourists to join the tour. For example, when the maximum is 48 , but the group size is 49 or 50 , the $49^{\text {th }}$ and $50^{\text {th }}$ group members are allowed to join the tour. In the second scenario, if the group is about 70 people, the management separates them into two groups to visit different sites or to visit the same site but at different times, for conservation considerations. The park management has the final say on where and when tourist groups go because they are the only authority issuing visiting permission to tourism sites within the park. Without this permission, forest rangers do not allow tourist groups to enter the sites, even when coming with travel agencies that are cooperating with the park.

This approach in carrying capacity management provides certain benefits to Vietnamese park system. First, the intervention point has a clear direction on when to make further arrangement regarding tourist arrivals. Second, the degree of intervention is less subjective due to the transparency in the regulation of maximum numbers (Con Dao National Park Management Board, 2016). Moreover, as stated by an informant at Con Dao NP, "the management objectives in Vietnamese parks are not only about economic benefits, but also about environmental conservation and sustainability”.

\section{Discussions}

\section{Three Approaches to the Implementation of Carrying Capacity}

Three approaches to the implementation of carrying capacity in Vietnam NPs were found, including 1) a laissez-faire approach, 2) a relaxed approach, and 3) a strict approach. Among these approaches, the first one is found to be the most popular in the Vietnamese park system. Apart from the major Ba Vi and Cuc Phuong NPs, there are more parks applying this method, such as Nam Cat Tien NP and Bach Ma NP. As discussed in the obstacles for capacity implementation, this approach follows the typical management style and attitude of the top-down management policy in Vietnam. Park management does 
not want to act, while there is no official action from the central government. The biggest disadvantage of this passive governance is that it is hard to fulfil the triple mandate of park management.

The strict approach is suggested to be the ideal method to obtain the triple mandate of park management. The advantage of this approach is the decision on the intervention point of capacity management. Considering the reactions of the ecosystem toward park management decisions, the judgment of the intervention point in Con Dao NP is objective - which is unique in developing countries (Prato, 2009). At the same time, Con Dao NP is the very first park in Vietnam and the region to apply this approach (i.e., used since 2016). This might cause a certain potential risk that needs the testimony of time to prove its success.

Considering the aforementioned advantages and disadvantages of laissez-faire and strict approaches, it is suggested that the most suitable capacity management approach for Vietnam is the relaxed one. It is deemed as unrealistic to require all park management boards in Vietnam to use Con Dao NP and its current strict approach as a role model. A more balance statement is to apply the model of PNKB NP with the assistance of an organization like the BCA. However, overcoming the shortcomings of the relaxed approach, one condition need to be added. Park management boards need to acquire a know-how of carrying capacity management and its intervention points. As such, they can independently develop policies for capacity management of their own and most suitable to the specific features of their parks. This newly adapted 'relaxed' approach is likely to be best suited for the case of developing countries such as Vietnam. While literature on Southeast Asian NPs lacks historical and regional context towards the implementation of capacity management, these identified approaches from Vietnamese NPs can be of reference for the region.

\section{Visitor Management Tools and the Approaches to the Implication of Carrying Capacity}

Based on the discussion of the visitor management tools in the literature, the above three approaches were analysed in terms of Management by Objective (MBO) and Decision Rules. Findings are summarized in Table 3.

Parks adopting laissez-faire and relaxed approaches do not apply any indicators or standards of MBO and decision rules. The interviewees of those parks responded that the concept of carrying capacity is unrealistic for them. It is claimed that the concept was too complicated to apply while there was a lack of ad-hoc knowledge and support from the Vietnamese government for its implementation.

Con Dao NP, which applies the strict approach, claimed to consider all state-of-the- 
This is a post-referred version of the paper published in Asia Pacific Journal of Tourism Research, 22:10, 1005-1020, DOI: 10.1080/10941665.2017.1359194

art factors while implementing carrying capacity management, including the three characteristics of MBO and the two internal forces of the crisp decision rule. The carrying capacity for each site is decided based on the numbers of tourists and their activities, and at the same time considers the natural environment.

Table 3. Carrying Capacity Development Stages in the Vietnamese Park System

\begin{tabular}{|c|c|c|c|c|}
\hline Characteristics & $\begin{array}{c}\text { Laissez-faire } \\
\text { approach } \\
\text { (Ba Vi \& Cuc } \\
\text { Phuong NPs) }\end{array}$ & $\begin{array}{c}\text { Relaxed approach } \\
\text { (Phong Nha - Ke } \\
\text { Bang NP) }\end{array}$ & $\begin{array}{l}\text { Strict approach } \\
\text { (Con Dao NP) }\end{array}$ & References \\
\hline $\begin{array}{l}\text { MBO management } \\
\text { objectives }\end{array}$ & $\begin{array}{l}\text { Economic } \\
\text { considerations }\end{array}$ & $\begin{array}{l}\text { Economic or } \\
\text { commercial } \\
\text { considerations }\end{array}$ & $\begin{array}{l}\text { Environmental } \\
\text { conservation and } \\
\text { sustainability }\end{array}$ & $\begin{array}{l}\text { Manning } \\
\text { (2001) }\end{array}$ \\
\hline $\begin{array}{l}\text { MBO-associated } \\
\text { indicators }\end{array}$ & Not available & Not available & $\begin{array}{l}\text { Nature, society and } \\
\text { management }\end{array}$ & $\begin{array}{l}\text { Manning } \\
\text { (2001) }\end{array}$ \\
\hline $\begin{array}{l}\text { MBO standards of } \\
\text { quality }\end{array}$ & Not available & $\begin{array}{l}\text { Mass tours: not } \\
\text { available; } \\
\text { Adventure tours: } \\
\text { visiting permission of } \\
\text { park management } \\
\text { board }\end{array}$ & $\begin{array}{l}\text { Visiting permission of } \\
\text { park management } \\
\text { board }\end{array}$ & $\begin{array}{l}\text { Manning } \\
\text { (2001) }\end{array}$ \\
\hline $\begin{array}{l}\text { Crisp decision rule: } \\
\text { current status of park } \\
\text { ecosystem }\end{array}$ & Not available & $\begin{array}{l}\text { A research project of } \\
\text { ecosystem change, } \\
\text { yet not in use for } \\
\text { tourism management }\end{array}$ & $\begin{array}{l}\text { Based on the guidelines } \\
\text { in Attachment } 6 \text { (Le, } \\
\text { 2015, p.105) }\end{array}$ & $\begin{array}{l}\text { Leopold et al. } \\
\text { (1963); } \\
\text { Prato (2009) }\end{array}$ \\
\hline $\begin{array}{l}\text { Crisp decision rule: } \\
\text { park ecosystem reacts } \\
\text { to management actions }\end{array}$ & Not available & Not available & Yes & $\begin{array}{l}\text { Leopold et al. } \\
\text { (1963); } \\
\text { Prato (2009) }\end{array}$ \\
\hline $\begin{array}{l}\text { Renew the maximum } \\
\text { number of carrying } \\
\text { capacity application }\end{array}$ & Not available & Not available & Yes. Twice yearly. & $\begin{array}{l}\text { Leopold et al. } \\
\text { (1963); } \\
\text { Prato (2009) }\end{array}$ \\
\hline $\begin{array}{l}\text { Stochastic decision } \\
\text { rule: changing status of } \\
\text { selected ecosystem } \\
\text { indicators }\end{array}$ & Not available & Not available & $\begin{array}{l}\text { Yes. Three } \\
\text { departments: } \\
\text { ecotourism unit, } \\
\text { scientific and } \\
\text { conservation unit, and } \\
\text { forest ranger unit }\end{array}$ & Prato (2007) \\
\hline
\end{tabular}




\begin{tabular}{llll}
\hline & & & Andriantiatsah \\
Fuzzy decision rule: & Not available $\quad$ Not available & Yes & oliniaina et al. \\
mathematical way & & & (2004); \\
& & & Klir \& Yuan \\
& & & (1995) \\
\hline
\end{tabular}

With the passage of time, the intervention point in park management switched from entirely subjective (i.e., the original concept of carrying capacity) to less subjective (i.e., all alternatives of MBO approaches). State-of-the art tools, such as the fuzzy adaptive management approach (operated by the fuzzy decision rule), are claimed to overcome two uncertainty factors of internal forces (Prato, 2009). Thus, the intervention point considered the biophysical features (e.g., the current status of the ecosystem), and the interaction and interdependence between the environmental factors and social carrying capacity (e.g., the reaction of the ecosystem to management actions).

\section{Park Management Models and the Approaches to the Implication of Carrying Capacity}

In the new era of SUF's management policy, the Vietnamese park system has witnessed the existing of two management models simultaneously, namely the parastatal model and public and for-profit model (Ly \& Xiao, 2016a). Such public-private management practices, which aim for better efficiency and effectiveness and determine the best alternative for fulfilling the triple mandate of park management (Su \& Xiao, 2009), however, are not a guarantee for the implementation of carrying capacity. The public and for-profit model is not always a promise of capacity implementation, such as the cases of PNKB NP and Con Dao NP. At the same time, the parastatal model seems not to always support the implementation of carrying capacity. In fact, most of the cases show that park managers would prefer to operate the visitor control issue under a freestyle practice (e.g., $\mathrm{Ba} \mathrm{Vi}$ and Cuc Phuong NPs). Under the current top-down management practice in Vietnam, reformation is not favourable in the bureaucratic system for both management models. To what extent the carrying capacity management is applied in a Vietnamese national park depends on the willingness to commit to a new management tool.

\section{Obstacles for Implementing Carrying Capacity Management}

Findings of the current study show that most Vietnamese parks refuse to use capacity management tools to govern visitor numbers, including those parks applying the laissezfaire and relaxed approaches. The major reasons for this are shortcomings in ad-hoc knowledge, lack of government support and guidelines, absence of the will of change, deficiencies in collaboration with other parks, mass tourism development and financial 
quotas.

First, interviews with informants who were top authorities of NPs revealed very elementary knowledge towards the concept of carrying capacity and its management tools. Second, although the Vietnamese Government has had carrying capacity management policy since 2007 (Ministry of Agriculture and Rural Development, 2007), the policy includes no clear guidelines for executing the policy, and makes no suggestions for suitable tools to carry out capacity management. Meanwhile, academic sustenance for carrying capacity application in a Vietnamese context is out-of-dated and there is no practical case study for adaptive management (Tran et al., 2007; Vo, 2008).

Fourth, in the setting of ecotourism, the application of carrying capacity management tools is critical, yet most Vietnamese NPs are instead focusing on mass tourism. Meanwhile, the financial quotas required by the central government are a further justification for mass tourism development. Parks also need to generate an income from selling tickets to maintain their current management teams. In developing countries such as Vietnam, tourism policies tend to focus on expanding international tourist arrivals in order to develop the national economies (Ghimire, 2001). In this case, economic benefits seem to overshadow ecological considerations (Pigram \& Jenkins, 2006), hence carrying capacity is likely to be neglected.

Fifth, the most important internal obstacle is the lack of willingness to commit to and use a new management tool. The case of the strict approach to carrying capacity management (Con Dao NP) may show that the willingness and determination of a park's management team can overcome the obstacles listed above. Together with the willingness, it is revealed that the restrictions due to a status, such as the World Heritage status of PNKB NP, can help overpower those difficulties. Most of tourist sites within this park do not apply any capacity control. However, due to the high risk of losing the status while taking tourists to the strictly protected areas of the park without limits (i.e., the Hang En Cave and Son Doong Cave tours), the park has applied the capacity control seriously, yet, with a passive attitude. For the developing countries, where economic value is desired, the nomination of UNESCO World Heritage sites means a promise for tourist arrivals in the area (Ma et al., 2009; Pigram \& Jenkins, 2006). This suggests a middle ground solution (i.e., relaxed approach) for carrying capacity management in Vietnam.

Lastly, an important problem of the Vietnamese park system is the deficiency of collaboration or communication between parks. The management teams of the various NPs seem not to exchange information or collaborate with each other on carrying capacity management. This is the major reason leading to the current different conditions of carrying capacity application. Most park management officers were unaware of the situations of other parks with the claim that "there is no national park in Vietnam applying 
the carrying capacity tool”. With the help of communication, other parks could also absorb the relaxed approach of PNKB NP and, ideally, the strict approach of Con Dao NP.

\section{Conclusions}

Spanning 40 years, literature on carrying capacity has established several visitormanagement frameworks, as well as enhancements to alternative tools that carrying capacity management provides (Manning, 2001; Prato, 2009). The application of carrying capacity management remains a challenge for managers of NPs and PAs. Economic constraints make it harder to implement carrying capacity management in developing countries (Ma et al., 2009; Pigram \& Jenkins, 2006). This study thus has investigated the concept and its application to Vietnam in order to understand the current situation, as well as to understand the applicability of the concept to the general context of developing countries.

Investigations from five NPs revealed three situations of carrying capacity management in Vietnamese parks, including 1) a laissez-faire approach, meaning zero regulation from local authorities, 2) a relaxed approach, meaning irregular policies for various cases and for different sites, and 3) a strict approach, meaning pre-established rules for all tourist sites. With the first two approaches, the intervention point is highly subjective, passive and determined on a case-by-case basis. Managers in these NPs decide which situations require interventions based on their "feelings" and "experiences". Only in the case of strict management-in Con Dao NP-there is a maximum number of visitors for each tourist site pre-established.

Moreover, this study suggests that economic considerations are acting as a constraint to the implementation of carrying capacity management in developing countries. Most Vietnamese parks are striving to increase their tourist arrivals for financial reasons. Our findings also reveal other obstacles for implementing carrying capacity in Vietnam, including shortcomings in ad-hoc knowledge, lack of government support and guidelines, deficiency of collaboration between parks, mass tourism development and unwillingness on the part of the park authorities. The current study also reveals that the park management model has no influence on the application of carrying capacity. Only willingness and determination from inside, or a pressure from outside (e.g. World Heritage status) can help national parks to overcome these obstacles.

The case of Con Dao NP is suggested as a good role model for other parks in Vietnam to learn from. Although economic benefits are vital for the improvement of parks in a developing country, the management of carrying capacity is necessary for the sustainable development and protection of national parks. Nonetheless, there are two concerns. First, the implementation of carrying capacity management in Con Dao NP 
began only recently, in March 2016 (Con Dao National Park Management Board, 2016). The operation needs more time to prove its effectiveness and the efficiency of its regulations. Second, the differences in terms of terrain between Con Dao maritime parks and the other mountainous parks of Vietnam could create issues in adaptive management. These concerns could inspire follow-up studies, such as a case study focusing on Con Dao NP, in order to investigate the effectiveness of the strict approach. Nevertheless, the solution of Con Dao NP towards capacity management is somewhat too radical and difficult for most of Vietnamese parks. The findings suggested that park management boards can apply the 'relaxed' approach with an active attitude, especially know-how learned from the assistance organization.

Although carrying capacity has been mentioned in studies concerning national parks in Vietnam as well as in other Southeast Asian countries, the issue either was only briefly discussed or focused on creating formulas for calculating carrying capacity. The current study took another approach in providing a nation-wide picture of the current situation regarding the implementation of carrying capacity in Vietnamese parks. It has identified three approaches to its implementation in national parks, as well as revealed related major constraints for developing countries. In addition to theoretical contributions, the study also provides practical implications for developing countries and Vietnam. By identifying the challenges and successful cases of the application of carrying capacity in Vietnamese parks, findings can be helpful for park authorities to learn for their practices in order to achieve the triple mandates of park management. The research results can benefit academics, the Vietnamese government and park managers in establishing suitable and applicable carrying capacity policy and implemental guidance for the Vietnamese park system. Finally, the practical experience of Vietnam's park situation may facilitate transferability of carrying capacity to other countries in Southeast Asia. 
This is a post-referred version of the paper published in Asia Pacific Journal of Tourism Research, 22:10, 1005-1020, DOI: 10.1080/10941665.2017.1359194

\section{References}

Andriantiatsaholiniaina, L. A., Kouikoglou, V. S., \& Phillis, Y. A. (2004). Evaluating strategies for sustainable development: Fuzzy logic reasoning and sensitivity analysis. Ecological Economics, 48(2), 149-172.

Bazeley, P. (2007). Qualitative data analysis with NVivo. London: Sage.

Beunen, R., Regnerus, H. D., \& Jaarsma, C. F. (2008). Gateways as a means of visitor management in national parks and protected areas. Tourism Management, 29(1), 138-145.

Brandt, J., \& Holmes, E. (2011). Conditions for the management of carrying capacity in the parks of parks \& benefits.

Buckley, R. (1999). An ecological perspective on carrying capacity. Annals of Tourism Research, 26(3), 705-708.

Ceballos-Lascuráin, H. (1996). Tourism, ecotourism, and protected areas: The state of nature-based tourism around the world and guidelines for its development. Cambridge: IUCN.

Cifuentes, M. (1992). Determinación de capacidad de carga turística enáreas protegidas [Determination of tourist carrying capacity in protected areas]. Bib. Orton IICA / CATIE.

Con Dao National Park Management Board. (2016). Quyết định ban hành Quy định về sức chứa của môi truò̀ng tại các tuyến, điểm tham quan, du lịch sinh thái trong phạm vi quản lý của Vuoòn quốc gia Côn Đảo [Decision regarding Regulations on environmental carrying capacity management for all tours and ecotourism sites within Con Dao National Park]. Ba Ria- Vung Tau, Vietnam: Con Dao National Park Management Board.

Dasmann, R. (1964). Wildlife biology. New York: John Wiley \& Sons.

Eagles, P. F. J. (2009). Governance of recreation and tourism partnerships in parks and protected areas. Journal of Sustainable Tourism, 17(2), 231-248.

Eagles, P. F. J. \& Hallo, J. C. (2013). Parks and Protected Areas in Canada and the United States. In H. Kinetics (Ed.), Introduction to Recreation and Leisure (2 ${ }^{\text {nd }}$ ed.) (pp.93-126). Champaign, IL: Human Kinetics.

Eagles, P. F. J., \& McCool, S. F. (2002). Tourism in national parks and protected areas: Planning and management. New York: CABI.

Emphandhu, D., Yemin, T., Pattanakiat, S., Tantasirin, C., Ruschano, R., Chettamart, S., Nasa, M. (2006, September). Recreation carrying capacity analysis at Khao Leam Ya Mu Ko Samed National Park, Thailand. Paper presented at the Third International Conference on Monitoring and Management of Visitor Flows in Recreational and Protected Areas, Rapperswil, Switzerland.

Foster, A. (2004). A nonlinear model of information-seeking behavior. Journal of the American Society 
This is a post-referred version of the paper published in Asia Pacific Journal of Tourism Research, 22:10, 1005-1020, DOI: 10.1080/10941665.2017.1359194

for Information Science \& Technology, 55(3), 228-237.

Ghimire, K. B. (2001). The growth of national and regional tourism in developing countries: An overview. In K. B. Ghimire (Ed.), The Native tourist: Mass tourism within developing countries (p.129). London: Earthscan.

Glaser, B., \& Strauss, A. (1967). The discovery of grounded theory: Strategies for qualitative research. New York: Aldine.

Graefe, A. R., Kuss, F. R., \& Vaske, J. J. (1990). Visitor impact management: The planning framework. Washington, D.C.: National Parks and Conservation Association.

Hammitt, W. E., \& Cole, D. N. (1998). Wildland recreation: Ecology and management. New York: John Wiley \& Sons.

Hennink, M., Hutter, I., \& Bailey, A. (2011).Qualitative research methods. London: Sage.

Hof, M., \& Lime, D. W. (1997). Visitor experience and resource protection framework in the national park system: Rationale, current status, and future direction. (No. INT-371) (pp. 29-36). Ogden, UT: USDA Forest Service General Technical Report. Retrieved from http://www.treesearch.fs.fed.us/pubs/23907.

Hsieh, H. F., \& Shannon. S. E. (2005). Three approaches to qualitative content analysis. Qualitative Health Research, 15(9), 1277-1288.

ICEM (2003). Lao PDR national report on protected areas and development. Review of protected areas and development in the lower Mekong River Region. Indooroopilly, Queensland, Australia: ICEM.

Ismail, M. M., Jaafar, M., \& Mohamad, D. (2015). Social carrying capacity of ecotourism national park: Case study of national park Kual Tahan, Malaysia. Journal of the Malaysian Institute of Planners, 8, $1-10$.

Kerkvliet, J., \& Nowell, C. (2000). Tool for recreation management in parks: The case of the greater Yellowstone’s blue-ribbon fishery. Ecological Economics, 34, 89-100.

Klir, G. J., \& Yuan, B. (1995). Fuzzy sets and fuzzy logic: Theory and applications. Upper Saddle River, NJ: Prentice-Hall.

Kuss, F. R., Graefe, A. R., \& Vaske, J. J. (1990). Visitor impact management: A review of research. Washington, D.C.: National Parks and Conservation Association.

Le, H. B. (Ed.). (2015). Bảo vệ môi trường du lịch [Protecting tourism environment]. Ho Chi Minh: Industrial University of Ho Chi Minh City.

Le, H. B., Thai, L. N., Nguyen, T. T. N., Le, H., Thai, V. B., \& Vo, D. L. (2009). Du lịch sinh thái [Ecotourism] (2nd ed.). Ho Chi Minh: Science and Technology Press. 
This is a post-referred version of the paper published in Asia Pacific Journal of Tourism Research, 22:10, 1005-1020, DOI: 10.1080/10941665.2017.1359194

Leopold, A. S., Cain, S. A., Cottam, C. M., Garibelson, I. N., \& Campbell, T. L. (1963). Wildlife management in the national parks. Transactions of the North American Wildlife Resources Conference, 28, 29-44.

Lime, D. W., \& Stankey, G. H. (1971). Carrying capacity: Maintaining outdoor recreation quality. In Recreation symposium proceedings (pp. 174-184). USDA Forest Service.

Lincoln, Y., \& Guba, E. (1985). Naturalistic inquiry. Beverly, CA: Sage.

Lindberg, K., McCool, S., \& Stankey, G. (1997). Rethinking carrying capacity. Annals of Tourism Research, 24(2), 461-465.

Linestone, H. A., \& Turoff, M. (1975). The Delphi method: Techniques and applications. Reading: Addison-Wesley.

Loucks, D. P. (1995). Developing and implementing decision support systems: A critique and a challenge. Journal of the American Water Resources Association, 31(4), 571-582.

Ly, T. P. (2015). Assessment of ecotourism management in a strictly protected area of a National Park: Hang En Cave, Vietnam, The Athens Jean Monnet Papers, Jean Monnet European Center of Excellence - National and Kapodistrian University of Athens, No. 5, May 2015.

Ly, T. P., \& Xiao, H. (2016a). The choice of a park management model: A case study of Phong Nha- Ke Bang National Park in Vietnam, Tourism Management Perspectives, 17, 1-15.

Ly, T. P., \& Xiao, H. (2016b). An innovative model of park governance: Evidence from Vietnam, Journal of Ecotourism, 15(2), 99-121.

Ma, X.-L., Ryan, C., \& Bao, J.-G. (2009). Chinese national parks: Differences, resource use and tourism product portfolios. Tourism Management, 30(1), 21-30.

Manning, R. E. (1985). Crowdings norms in back-country settings. Journal of Leisure Research, 17(2), 75-89.

Manning, R. E. (1999). Studies in outdoor recreation. Corvallis, Oregon: Oregon State University Press.

Manning, R. E. (2001). Visitor experience and resource protection: A framework for managing the carrying capacity of national parks. Journal of Park and Recreation Administration, 19(1), 93-108.

Manning, R. E., Valliere, W., Minteer, B., Wang, B., \& Jacobi, C. (2000). Crowding in parks and outdoor recreation: A theoretical, empirical, and managerial analysis. Journal of Park and Recreation Administration, 18(4), 57-72.

Mayring, P. (2000). Qualitative content analysis. Forum: Qualitative Social Research, 1(2). Retrieved from http://217.160.35.246/fqs-texts/2-00/2-200mayring-e.pdf.

Mekong Protected Areas (2003). Field study: Cambodia. Bokor, Kirirom, Kep and Ream National Park. Retrieved from http://www.mekong-protected-areas.org/cambodia/docs/cambodia_field.pdf . 
This is a post-referred version of the paper published in Asia Pacific Journal of Tourism Research, 22:10, 1005-1020, DOI: 10.1080/10941665.2017.1359194

Ministry of Agriculture and Rural Development. (2007). Ban hành quy chế Số 104/2007/QĐ-BNN quản lý các hoạt động du lịch sinh thái tại các vuờn quốc gia, khu bảo tồn thiên nhiên [Regulations No.104/2007/QĐ-BNN on management of ecotourism activities in national park and nature reserves]. Ministry of Agriculture and Rural Development, the Government of Vietnam.

Ministry of Agriculture and Rural Development. (2011). Thông tur Số 78/2011/TT-BNNPTNT quy định chi tiết thi hành Nghị định Số 117/2010/NĐ-CP ngày 24/12/2010 của Chính Phủ về tổ chức và quản lý hệ thống rùng đặc dụng [Circular No. 78/2011/TT-BNNPTNT on guide the implementation of the Decree No. 117/2010/NĐ-CP on organization and management of special use forest system]. Ministry of Agriculture and Rural Development, the Government of Vietnam.

More, T. (2005). From public to private: Five concepts of park management and their consequences. The George Wright Forum, 22(2), 12-20.

National Park Service. (1995). The visitor experience and resource protection implementation plan: Arches National Park. Denver: Denver Service Center.

Nguyen, T. K. D., Bush, S. R., \& Mol, A. P. J. (2016). The Vietnamese state and administrative comanagement of nature reserves. Sustainability, 8(3), 1-19.

Payne, R. J., \& Nilsen, P. W. (2008). Visitor planning and management. In P. Dearden \& R. Rollins (Eds.), Parks and protected areas in Canada: Planning and management ( $3^{\text {rd }}$ ed.) (pp. 169-199). Oxford: Oxford University Press.

Patton, M. (2008). Utilization-focused evaluation (4 ${ }^{\text {th }}$ ed.). Thousand Oaks, CA: Sage.

Pigram, J., \& Jenkins, J. (2006). Outdoor recreation management (2nd ed.). Abingdon: Routledge.

Plummer, R. (2009). Outdoor recreation: An introduction. New York: Routledge.

Posavac, E. (2011). Programme evaluation: Methods and case studies ( $8^{\text {th }}$ ed.). Upper Saddle River, NJ: Prentice-Hall.

Prato, T. (2001). Modeling carrying capacity for national parks. Ecological Economics, 39(3), 321-331.

Prato, T. (2007). Assessing ecosystem sustainability and management using fuzzy logic. Ecological Economics, 61(1), 171-177.

Prato, T. (2009). Fuzzy adaptive management of social and ecological carrying capacities for protected areas. Journal of Environmental Management, 90(8), 2551-2557.

Prato, T. (2012). Increasing resilience of natural protected areas to future climate change: A fuzzy adaptive management approach. Ecological Modelling, 242, 46-53.

QSR International. (2016). NVivo 10 research software for analysis and insight. Retrieved from http://www.qsrinternational.com/products_nvivo.aspx.

Shelby, B., \& Heberlein, T. A. (1986). Carrying capacity in recreation settings. Corvallis, OR: Oregon 
This is a post-referred version of the paper published in Asia Pacific Journal of Tourism Research, 22:10, 1005-1020, DOI: 10.1080/10941665.2017.1359194

State University Press.

Simón, F., Narangajavana, Y., \& Marqués, D. (2004). Carrying capacity in the tourism industry: A case study of Hengistbury Head. Tourism Management, 25(2), 275-283.

Stankey, G., \& Lime, D. (1973). Recreational carrying capacity: An annotated biography. (No. INT-3). USDA Forest Service General Technical Report.

Stankey, G., Cole, D., Lucas, R., Peterson, M., Frissell, S., \& Washburne, R. (1985). The limits of acceptable change (LAC) system for wilderness planning. (No. INT-176). Ogden, UT: USDA Forest Service General Technical Report.

Su, D., \& Xiao, H. (2009). The governance of nature-based tourism in China: Issues and research perspectives. Journal of China Tourism Research, 5, 318-338.

Sugumaran, R., Meyer, J., \& Davis, J. (2010). A web-based environmental decision support system for environmental planning and watershed management. In M. M. Fischer \& A. Getis (Eds.), Handbook of Applied Spatial Analysis (pp. 703-718). Springer Berlin Heidelberg. Retrieved from http://link.springer.com/chapter/10.1007/978-3-642-03647-7_33.

Sumner, E. (1936). Special report on a wildlife study of the High Sierra in Sequoia and Yosemite National Parks and adjacent territory. New York: U.S. Department of the Interior, National Park Service.

Suntikul, W. (2010). Tourism and political transition in reform-era Vietnam. In R. Butler \& W. Suntikul (Eds.), Tourism and political change (pp. 133-143). Oxford: Goodfellow Publishing.

Suntikul, W., Butler, R., \& Airey, D. (2010). Implications of political change on national park operations: Doi moi and tourism to Vietnam’s national parks. Journal of Ecotourism, 9(3), 201-218.

The Government of Vietnam. (2003). Quyết định Số.192/2003/QĐ-TTG của Thủ Tuóng Chính Phủ về phê duyệt chiến lược quản lý cho hệ thống các khu bảo tồn ở Việt Nam đến năm 2010 [Decision No.192/2003/QĐ-TTG of the Prime Minister to approve the management strategy for a protected areas system in Vietnam to 2010]. The Government, the Government of Vietnam.

The Government of Vietnam. (2006). Nghị định Số 23/2006/NĐ-CP về việc thực hiện các quy định của pháp luật về bảo vệ và phát triển rùng [Decree No. 23/2006/NĐ-CP on the implementation of the law on forest protection and development]. The Government, the Government of Vietnam.

The Government of Vietnam. (2010). Nghị định số 117/2010/NĐ-CP về tổ chức và quản lý hệ thống rùng đặc dụng [Decree No. 117/2010/NĐ-CP on organisation and management of the Special-use Forest system]. Hanoi, Vietnam: The Government of Vietnam.

Tran, N., Nguyen, T. L., Nguyen, D. T., Dang, M., \& Dinh, X. T. (2007). Tourism carrying capacity assessment for Phong Nha - Ke Bang and Dong Hoi, Quang Binh Province. VNU Journal of Science, 23, 80-87.

Vietnam National Administration of Tourism. (2017). Tourism statistics report. Retrieved from 
This is a post-referred version of the paper published in Asia Pacific Journal of Tourism Research, 22:10, 1005-1020, DOI: 10.1080/10941665.2017.1359194

http://www.vietnamtourism.com/index.php/news/cat/20.

Vo, Q. (2008). Vận dụng công thức của A.M.Cifuentes và H. Ceballos-Lascurain để áp dụng tính toán sức chúa cho các khu du lịch sinh thái ở Việt Nam [The use of the formulas of Cifuentes and CeballosLascurain to calculate the carrying capacity of ecotourism sites at Vietnam]. Institute for Tourism Development Research.

World Commission on Environment and Development. (1987). Our common future. Oxford: Oxford University Press. Retrieved from http://ukcatalogue.oup.com/product/9780192820808.do\#.UePExm0yjDo. 